\title{
Calculating the Output Power of Photovoltaic Cells on Top of Electric and Hybrid Electric Vehicles
}

\author{
Christian Schuss*, Tapio Fabritius ${ }^{\dagger}$, Bernd Eichberger ${ }^{\ddagger}$, and Timo Rahkonen* \\ ${ }^{*}$ Circuits and Systems (CAS) Research Unit, University of Oulu, Finland; email: christian.schuss, timo.rahkonen@oulu.fi \\ †Optoelectronics and Measurement Techniques Research Unit, University of Oulu, Finland; email: tapio.fabritius@oulu.fi \\ ${ }_{\ddagger}^{\ddagger}$ Institute of Electronic Sensor Systems, Graz University of Technology, Austria; email: bernd.eichberger@tugraz.at
}

\begin{abstract}
This paper investigates the potential output power of a photovoltaic (PV) installation on top of battery-powered electric vehicles (BEVs) and hybrid electric vehicles (HEVs). Firstly, we discuss the available area on the roof of BEVs and HEVs for deploying PV cells. Secondly, we verify the impact of the curved surface on the available output power of photovoltaics. Furthermore, we discuss the impact of the curved surface and the ambient conditions on the possible alignment of PV cells. Here, we present a method of calculating the effective area of PV cells, useful for PV simulation models and calculating the available output power of PV cells with different longitudinal angles. Finally, we verify our method within experiments and present the results of them, showing that the model predicts the output power of PV cells with an accuracy better than $2.5 \%$.

Index Terms-battery-powered electric vehicle, data acquisition, environmental data, hybrid electric vehicle, measurement, photovoltaic energy, simulation, solar energy.
\end{abstract}

\section{INTRODUCTION}

At present, solar energy is the most promising energy source [1], in particular to substitute energy gained from fossil fuels such as oil, coal and gas [2]. In future, the opportunity is given to integrate photovoltaic (PV) cells into the roof of battery-powered vehicles (BEVs) and hybrid electric vehicles (HEVs). As a result, the electrical driving range of these types of vehicles can be extended remarkably [3]-[6]. Similarly, photovoltaics can be used to power a charging station for BEVs and HEVs, for example [7].

Due to the technical development of automobiles, their electricity consumption has grown significantly over the past years and electronic control units (ECUs) have become the key components in automotives [8]. Their objectives include the control of the power train, as well as safety and comfort requirements. In the case of $\mathrm{HEVs}$, an additional demand of 100 Watts electrical power increases the fuel consumption by 0.1 to 0.2 litres per 100 kilometres [8], [9]. Similarly, in the case of BEVs, the electrical driving distance is reduced by electronics. In order to maximize the operational range of HEVs and BEVs, alternative energy harvesting methods such as photovoltaics are considered.

It is clear that the available output power obtainable from photovoltaics is too low to provide enough energy for the propulsion of BEVs and HEVs directly [10]. Hence, we propose to use PV energy as an energy range extender (ERE) and, thereby, reduce the amount of electricity which has to be provided by the alternator or energy demanded from the power grid for charging the high-voltage battery [11]. PV energy can be supplied to non-critical systems within the on-board power grid when driving. Likewise, the high-voltage battery can be charged by the PV installation when the vehicle is parked. The available area on top of BEVs and HEVs is limited and the curved shape of the roof has an impact on the available output power of the PV installation on top of BEVs and HEVs [3][6]. To optimize the ERE performance in these circumstances, more sophisticated methods and models are needed in order to estimate the power generation of photovoltaics.

\section{EXPERIMENTAL SETUP}

\section{A. Photovoltaics within Experiments}

Since the available space on top of BEVs and HEVs is limited we suggest using superior PV cells with high efficiencies and high output currents. As a result, a significant amount of PV energy can be produced and provided to the on-board power supply of vehicles. Thus, a monocrystalline silicon (mono-Si) PV cell was used in experiments and simulations. The dimension of one PV cell is 156 x 156 millimetres. Table I summarises the most important output parameters obtained from the datasheet of the manufacturer Blue Chip Energy $\mathrm{GmbH}$.

TABLE I

Data of the Blue Chip PV CELl

\begin{tabular}{|c|c|}
\hline Parameter & Value \\
\hline$P_{m p p}$ & $4.140 \mathrm{~W}$ \\
\hline$V_{m p p}$ & $0.515 \mathrm{~V}$ \\
\hline$I_{m p p}$ & $8.039 \mathrm{~A}$ \\
\hline$V_{o c}$ & $0.613 \mathrm{~V}$ \\
\hline$I_{s c}$ & $8.602 \mathrm{~A}$ \\
\hline
\end{tabular}

AM1.5; $\lambda=1,000 \mathrm{~W} / \mathrm{m}^{2} ; T_{C}=25{ }^{\circ} \mathrm{C} ;$ standard test conditions (STC)

\section{B. Possible Number of PV Cells}

Fig. 1 shows the experimental vehicle, a Toyota Prius, which was used for measurements and analysing the impact of different alignments and orientations of PV cells towards the sun. In addition, the experimental vehicle was used to study the impact of ambient conditions on the output performance of PV cells. Fig. 2 illustrates the available area for PV cells on the roof of the Toyota Prius. 


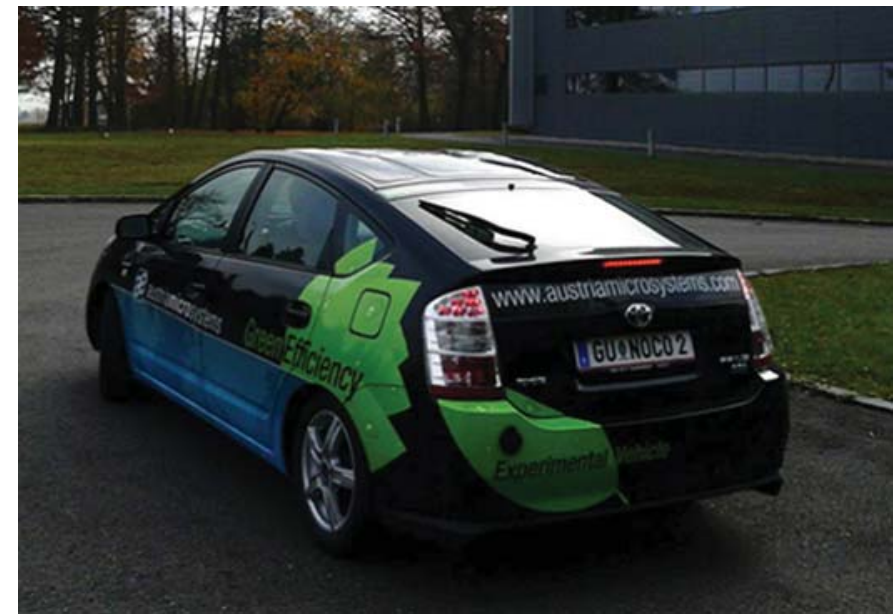

Fig. 1. Experimental vehicle with integrated PV cells

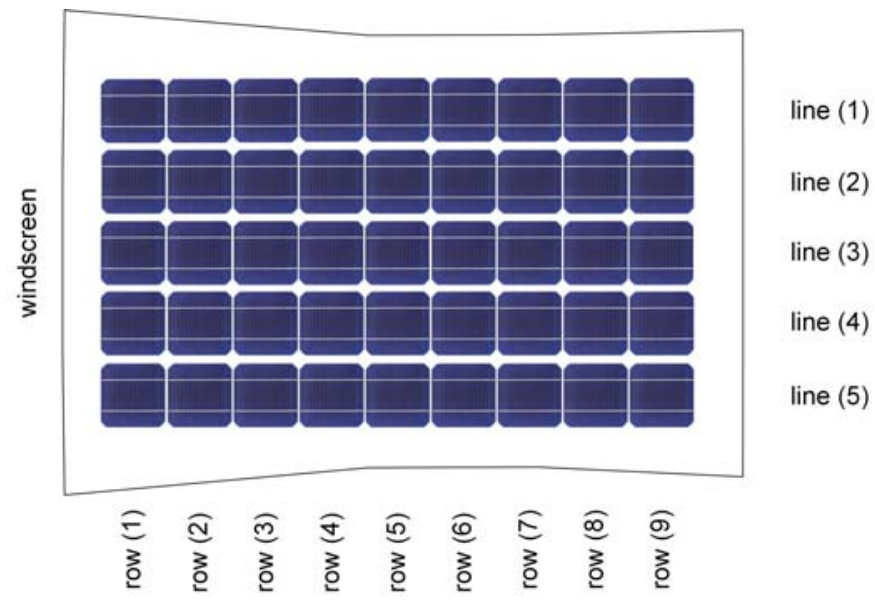

Fig. 2. PV installation on top of the experimental vehicle

Due to the curved shape of the roof of the Toyota Prius, it is not possible to utilise $100 \%$ of the roof's area for the installation of PV cells [4]. On average, the available area on the roof of BEVs and HEVs varies between 1.5 and $2 \mathrm{~m}^{2}$. The roof of the Toyota Prius is wider at the front than at the back, while it is even smaller in the middle. Hence, we have chosen a number of $45 \mathrm{PV}$ cells $\left(n_{\text {cells,row }}=9, n_{\text {cells,line }}=5\right)$, as illustrated in Fig. 2. PV cells are connected in series or parallel in order to increase the output power. When connecting PV cells in series, the open-circuit voltage $\left(V_{o c}\right)$ increases, while in parallel structures, the short-circuit current $\left(I_{s c}\right)$ increases.

\section{The Effective Area of PV Cells}

As a result of the curved shape of the roof of the Toyota Prius, the five PV cells in each row have a different orientation towards the sun. Table II summarises the longitudinal angles $(\beta)$ of the PV cells from row number (1) to (9). The street represents the horizontal plane. Based on these longitudinal angles, there is a difference in the orientation of $24^{\circ}$ between the PV cells in row number (1) and row number (9). Fig. 3 shows the effective PV cell area $\left(A_{\text {eff }}[\%]\right)$ based on the different orientation of PV cells at different solar altitude angles $(\alpha)$. $A_{\text {eff }}$ was calculated in MATLAB ${ }^{\circledR}$ by using the perpendicular area without taking diffuse irradiation and possible total reflections into account, as follows

$$
A_{\text {eff }}=\cos \left(\alpha+\beta-90^{\circ}\right) \times 100
$$

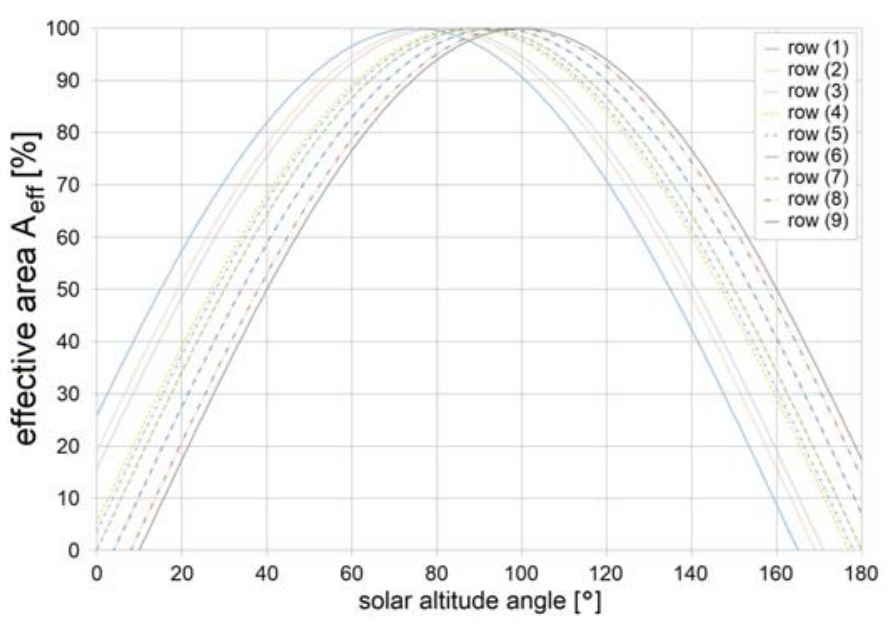

Fig. 3. Effective PV cell areas at different solar altitude angles

Table III presents the effective area $\left(A_{\text {eff }}\right)$ calculated at different solar altitude angles. As seen in Table III, there is a significant difference in $A_{\text {eff }}$ between row (1) and row (9). Furthermore, the difference in $A_{\text {eff }}$ depends on the solar altitude angle ( $\alpha$ ). At $\alpha=90^{\circ}$, the difference in $A_{\text {eff }}$ between row (1) and (9) is less than 5\%, while at $\alpha=20^{\circ}$ and $\alpha=160^{\circ}$ the difference in $A_{\text {eff }}$ is about $40 \%$. Table IV shows effective areas for typical solar radiation altitudes in the City of Oulu, Finland, on the $3^{\text {rd }}$ of June.

In Table IV, it can be seen that the orientation of the PV cells towards the sun is not optimal on top of the Toyota Prius. For a better comparison, the calculated values for the effective area are normalised. The highest value in each row at a given solar altitude is considered to be $100 \%\left(A_{\text {eff, } \text { max }}\right)$, as obtained by Equation (2). In other rows, lower values are obtained due to the different orientation of the PV cell towards the sun. Table $\mathrm{V}$ presents the normalised effective area $\left(\hat{A}_{\text {eff }}\right)$ for typical solar altitude angles in Oulu, Finland.

$$
\hat{A}_{\text {eff }}=\frac{A_{\text {eff }, i}}{A_{\text {eff,max }}} \quad \text { whereas } \quad i=1,2, \ldots, 8,9
$$

\section{Output Behaviour of Photovoltaics}

Fig. 4 illustrates the characteristic non-linear output behaviour of a PV cell from the manufacturer Blue Chip Energy $\mathrm{GmbH}$ in the form of the $I-V$ (Current-Voltage) curve and $P$ - $V$ (Power-Voltage) curve. The point on the $I-V$ curve, in which the product of voltage and current, the power, becomes a maximum is referred to as the maximum power point (MPP). The available power in the MPP $\left(P_{m p p}\right)$ varies with changing ambient conditions such as the solar radiation level $(\lambda)$ and the PV cell temperature $\left(T_{c}\right)$ [12]. 
TABLE II

LONGitudial ANGLes of PV CELls ON THE ROOF OF THE TOYOTA PriUs

\begin{tabular}{|c|c|c|c|c|c|c|c|c|c|}
\cline { 2 - 9 } \multicolumn{1}{c|}{} & row (1) & row (2) & row (3) & row (4) & row (5) & row (6) & row (7) & row (8) & row (9) \\
\hline angle & $15^{\circ}$ & $12^{\circ}$ & $9^{\circ}$ & $3^{\circ}$ & $2^{\circ}$ & $0^{\circ}$ & $-3^{\circ}$ & $-7^{\circ}$ & $-9^{\circ}$ \\
\hline
\end{tabular}

TABLE III

Calculated effective ARea of PV Cells $\left(A_{\text {eff }}\right)$ At Different solar Altitude Angles $(\alpha), \alpha=20^{\circ}$ To $160^{\circ}$

\begin{tabular}{|c|c|c|c|c|c|c|c|c|c|}
\cline { 2 - 9 } \multicolumn{1}{c|}{} & \multicolumn{9}{c|}{ solar altitude angle $(\alpha)$} \\
\cline { 2 - 10 } \multicolumn{1}{c|}{} & $20^{\circ}$ & $40^{\circ}$ & $60^{\circ}$ & $75^{\circ}$ & $90^{\circ}$ & $105{ }^{\circ}$ & $120^{\circ}$ & $140^{\circ}$ & $160^{\circ}$ \\
\hline row (1) & $57.36 \%$ & $81.92 \%$ & $96.59 \%$ & $100.00 \%$ & $96.59 \%$ & $86.60 \%$ & $70.71 \%$ & $42.26 \%$ & $8.72 \%$ \\
\hline row (2) & $51.50 \%$ & $77.71 \%$ & $94.55 \%$ & $99.76 \%$ & $98.16 \%$ & $89.88 \%$ & $75.47 \%$ & $48.48 \%$ & $15.64 \%$ \\
\hline row (3) & $48.48 \%$ & $75.47 \%$ & $93.36 \%$ & $99.45 \%$ & $98.77 \%$ & $91.35 \%$ & $77.71 \%$ & $51.50 \%$ & $19.08 \%$ \\
\hline row (4) & $39.07 \%$ & $68.20 \%$ & $89.10 \%$ & $97.81 \%$ & $99.86 \%$ & $95.11 \%$ & $83.87 \%$ & $60.18 \%$ & $29.24 \%$ \\
\hline row (5) & $37.46 \%$ & $66.91 \%$ & $88.29 \%$ & $97.44 \%$ & $99.94 \%$ & $95.63 \%$ & $84.80 \%$ & $61.57 \%$ & $30.90 \%$ \\
\hline row (6) & $34.20 \%$ & $64.28 \%$ & $86.20 \%$ & $96.59 \%$ & $100.00 \%$ & $96.59 \%$ & $86.60 \%$ & $64.28 \%$ & $34.20 \%$ \\
\hline row (7) & $27.56 \%$ & $58.78 \%$ & $82.90 \%$ & $94.55 \%$ & $99.76 \%$ & $98.16 \%$ & $89.88 \%$ & $69.47 \%$ & $40.67 \%$ \\
\hline row (8) & $20.79 \%$ & $52.99 \%$ & $78.80 \%$ & $92.05 \%$ & $99.03 \%$ & $99.25 \%$ & $92.72 \%$ & $74.31 \%$ & $46.95 \%$ \\
\hline row (9) & $17.36 \%$ & $50.00 \%$ & $76.60 \%$ & $90.63 \%$ & $98.48 \%$ & $99.62 \%$ & $93.97 \%$ & $76.60 \%$ & $50.00 \%$ \\
\hline
\end{tabular}

TABLE IV

Calculated effective ARea of PV Cells $\left(A_{e f f}\right)$ At Different Solar Altitude Angles $(\alpha), \alpha=38^{\circ}$ To $44^{\circ}$

\begin{tabular}{|c|c|c|c|c|c|c|c|}
\cline { 2 - 8 } \multicolumn{1}{c|}{} & \multicolumn{9}{c|}{ solar altitude angle $(\alpha)$} & 42 & $43^{\circ}$ & $44^{\circ}$ \\
\cline { 2 - 8 } \multicolumn{1}{c|}{} & $38^{\circ}$ & $39^{\circ}$ & $40^{\circ}$ & $41^{\circ}$ & $83.87 \%$ & $84.80 \%$ & $85.72 \%$ \\
\hline row (1) & $79.86 \%$ & $80.90 \%$ & $81.92 \%$ & $82.90 \%$ & $79.86 \%$ & $80.90 \%$ & $81.92 \%$ \\
\hline row (2) & $75.47 \%$ & $76.60 \%$ & $77.71 \%$ & $78.80 \%$ & $77.71 \%$ & $78.80 \%$ & $79.86 \%$ \\
\hline row (3) & $73.14 \%$ & $74.31 \%$ & $75.47 \%$ & $76.60 \%$ & $70.71 \%$ & $71.93 \%$ & $73.14 \%$ \\
\hline row (4) & $65.61 \%$ & $66.91 \%$ & $68.20 \%$ & $69.47 \%$ & $69.47 \%$ & $70.71 \%$ & $71.93 \%$ \\
\hline row (5) & $64.28 \%$ & $65.61 \%$ & $66.91 \%$ & $68.20 \%$ & $66.91 \%$ & $68.20 \%$ & $69.47 \%$ \\
\hline row (6) & $61.57 \%$ & $62.93 \%$ & $64.28 \%$ & $65.61 \%$ & $61.57 \%$ & $62.93 \%$ & $64.28 \%$ \\
\hline row (7) & $55.92 \%$ & $57.36 \%$ & $58.78 \%$ & $60.18 \%$ & $57.92 \%$ & $57.36 \%$ & $58.78 \%$ \\
\hline row (8) & $50.00 \%$ & $51.50 \%$ & $52.99 \%$ & $54.46 \%$ & $54.46 \%$ & $55.92 \%$ \\
\hline row (9) & $46.95 \%$ & $48.48 \%$ & $50.00 \%$ & $51.50 \%$ & $52.99 \%$ & 54.45 \\
\hline
\end{tabular}

TABLE V

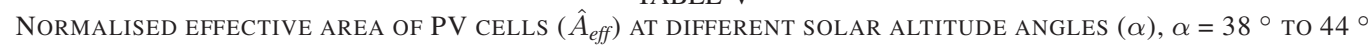

\begin{tabular}{|c|c|c|c|c|c|c|c|}
\cline { 2 - 8 } \multicolumn{1}{c|}{} & \multicolumn{7}{c|}{ solar altitude angle $(\alpha)$} \\
\cline { 2 - 8 } \multicolumn{1}{c|}{} & $38^{\circ}$ & $39^{\circ}$ & $40^{\circ}$ & $411^{\circ}$ & $42{ }^{\circ}$ & $43^{\circ}$ & $44{ }^{\circ}$ \\
\hline row (1) & $100.00 \%$ & $100.00 \%$ & $100.00 \%$ & $100.00 \%$ & $100.00 \%$ & $100.00 \%$ & $100.00 \%$ \\
\hline row (2) & $94.50 \%$ & $94.69 \%$ & $94.87 \%$ & $95.05 \%$ & $95.23 \%$ & $95.40 \%$ & $95.57 \%$ \\
\hline row (3) & $91.58 \%$ & $91.86 \%$ & $92.13 \%$ & $92.40 \%$ & $92.66 \%$ & $92.92 \%$ & $93.17 \%$ \\
\hline row (4) & $82.15 \%$ & $82.71 \%$ & $83.26 \%$ & $83.79 \%$ & $84.31 \%$ & $84.82 \%$ & $85.32 \%$ \\
\hline row (5) & $80.49 \%$ & $81.09 \%$ & $81.69 \%$ & $82.26 \%$ & $82.83 \%$ & $83.38 \%$ & $83.92 \%$ \\
\hline row (6) & $77.09 \%$ & $77.79 \%$ & $78.47 \%$ & $79.14 \%$ & $79.78 \%$ & $80.42 \%$ & $81.04 \%$ \\
\hline row (7) & $70.02 \%$ & $70.90 \%$ & $71.76 \%$ & $72.59 \%$ & $73.41 \%$ & $74.21 \%$ & $74.99 \%$ \\
\hline row (8) & $62.61 \%$ & $63.66 \%$ & $64.69 \%$ & $65.70 \%$ & $66.68 \%$ & $67.63 \%$ & $68.57 \%$ \\
\hline row (9) & $58.78 \%$ & $59.93 \%$ & $61.04 \%$ & $62.12 \%$ & $63.19 \%$ & $64.22 \%$ & $65.24 \%$ \\
\hline
\end{tabular}

\section{Available Output Power of PV Installations}

\section{A. PV Simulation Model}

Simulations are helpful for determining the potential output power of photovoltaics under different solar radiation levels. Commonly, the single diode model is used as an equivalent electric circuit for the simulation of one PV cell [14]-[17]. The short circuit-current of the PV cell $\left(I_{s c}\right)$ is directly proportional to the solar radiation level $(\lambda)$. In the case of the single-diode model, the output current $\left(I_{\text {out }}\right)$ can be obtained as follows 


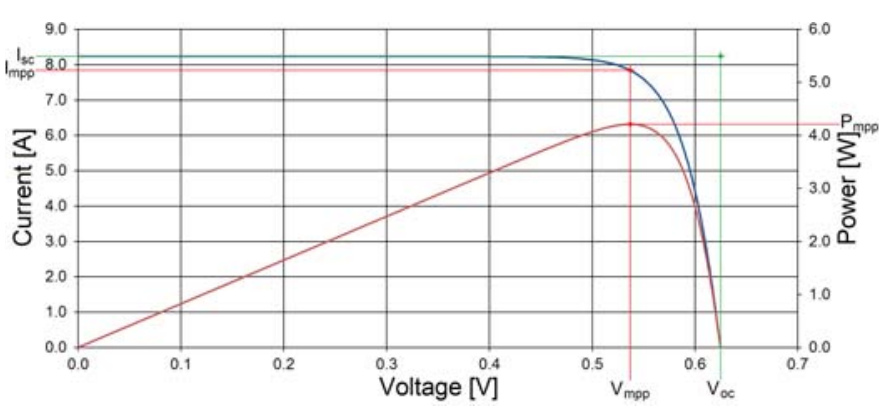

Fig. 4. $I-V$ curve and $P-V$ curve of a PV cell with parameters

$$
\begin{array}{r}
I_{\text {out }}=N_{p} I_{\text {ph }}-N_{p} I_{s}\left(e^{\frac{q\left(N_{p} V_{\text {out }}+N_{s} I_{\text {out }} R_{s}\right)}{N_{p} N_{s} A k T_{c}}}-1\right) \\
-\frac{\frac{N_{p}}{N_{s}} V_{\text {out }}+I_{\text {out }} R_{s}}{R_{\text {sh }}}
\end{array}
$$

where $N_{p}$ is the number of PV cells connected in parallel with one other; $I_{p h}$ is the photo current; $I_{s}$ is the saturation current; $q$ is the charge of an electron; $V_{\text {out }}$ is the output voltage of the PV cell; $N_{s}$ is the number of PV cells connected in series with one other; $R_{s}$ is the series resistance of the equivalent circuit; $A$ is the ideality factor of the p-n junction, $k$ is Bolzmann's constant; and $R_{s h}$ is the shunt resistance of the equivalent circuit, which is shown in Fig. 5. It is worth noting that there are several more equations required to fully describe and calculate the equivalent circuit of a PV cell.

For the PV installation on top of the Toyota Prius, PV cells can be connected in series and/or parallel with each other to form a PV panel [4], as illustrated in Fig. 6. For a single PV cell, $N_{s}$ and $N_{p}$ are equal to 1 . In PV simulations, one coefficient for the solar radiation level $(\lambda)$ and one for the cell temperature $\left(T_{c}\right)$ are applied. In other words, the assumption is made that each cell of the PV panel is exposed to an equal amount of sunlight and operates at the same temperature level. This assumption can be made in the case of conventional PV panels which are mounted onto flat surfaces, for example on the roof of a house.

If photovoltaics are mounted onto curved surfaces such as the top of a vehicle, each cell of the PV panel will obtain a different amount of sunlight and operate at a different temperature. The variation in output power depends on the solar altitude and alignment of individual PV cells of the panel towards the sun. This situation is comparable to partial shading of PV panels, which can occur temporarily during cloudy days or in the proximity of shading objects like trees [13]. In this paper, we focus on the effective area $\left(A_{\text {eff }}\right)$ to consider different longitudinal angles of PV cells towards the sun in PV simulation models.

\section{B. Experimental Verification of the Effective Area}

In the experiments, the front of the vehicle was orientated towards the sun. We collected data by measuring the characteristic $I$ - $V$ curves. Fig. 7 illustrates the block diagram of the measurement setup, while Fig. 8 shows the schematic diagram

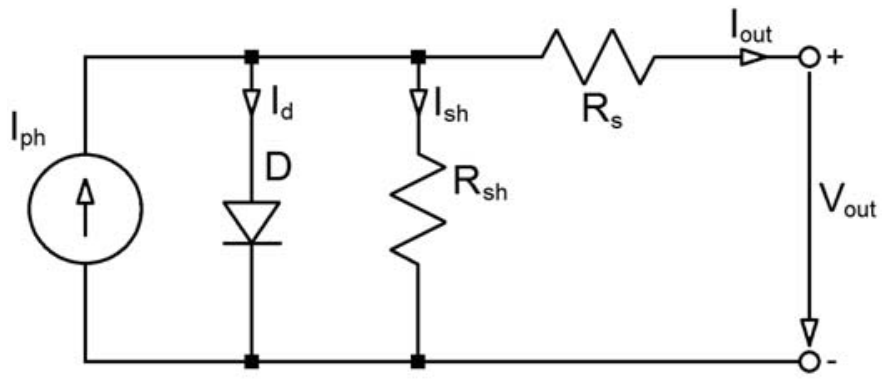

Fig. 5. Equivalent circuit of a PV cell

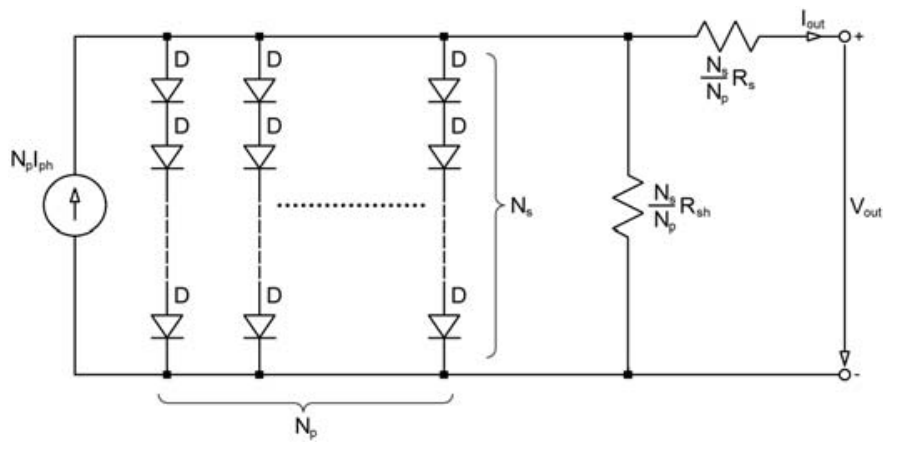

Fig. 6. Equivalent circuit of a PV panel

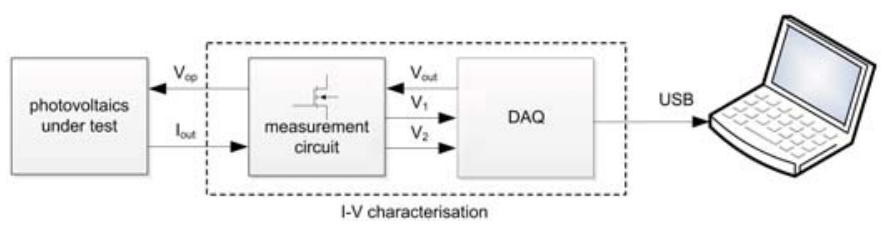

Fig. 7. Block diagram of the measurement setup

TABLE VI

MEASURED SOLAR RADIATION LEVEL $(\lambda)$ IN ROW (6)

\begin{tabular}{|c|c|}
\hline$\alpha$ & $\lambda$ \\
\hline $38^{\circ}$ & $570 \mathrm{~W} / \mathrm{m}^{2}$ \\
\hline $39^{\circ}$ & $590 \mathrm{~W} / \mathrm{m}^{2}$ \\
\hline $40^{\circ}$ & $620 \mathrm{~W} / \mathrm{m}^{2}$ \\
\hline $41^{\circ}$ & $630 \mathrm{~W} / \mathrm{m}^{2}$ \\
\hline $42^{\circ}$ & $640 \mathrm{~W} / \mathrm{m}^{2}$ \\
\hline $43^{\circ}$ & $650 \mathrm{~W} / \mathrm{m}^{2}$ \\
\hline $44^{\circ}$ & $660 \mathrm{~W} / \mathrm{m}^{2}$ \\
\hline
\end{tabular}

of the measurement circuit. Data was collected under outdoor environmental conditions. For that reason, we also measured the consistency of the environmental situation, meanwhile the operating voltage of photovoltaics was altered. For the obtained measurement results, an uncertainty (type A and type B) of $\pm 3 \%$ is considered. Table VI shows the measured solar radiation level $(\lambda)$ for the PV cell in row (6) with $\beta=0^{\circ}$ at different solar altitude angles $(\alpha)$. Table VII summarises the obtained power in the MPP $\left(P_{m p p}\right)$ for the PV cells in the different rows at different solar altitude angles. 
TABLE VII

Obtained POWER In THE MPP $\left(P_{m p p}\right)$ AT DifFERENT SOlar Altitude ANGLES $(\alpha), \alpha=38^{\circ}$ TO $44^{\circ}$

\begin{tabular}{|c|c|c|c|c|c|c|c|}
\hline & \multicolumn{7}{|c|}{ solar altitude angle $(\alpha)$} \\
\hline & $38^{\circ}$ & $39^{\circ}$ & $40^{\circ}$ & $41^{\circ}$ & $42^{\circ}$ & $43^{\circ}$ & $44^{\circ}$ \\
\hline row (1) & $3.12 \mathrm{~W}$ & $3.21 \mathrm{~W}$ & $3.42 \mathrm{~W}$ & $3.39 \mathrm{~W}$ & $3.36 \mathrm{~W}$ & $3.42 \mathrm{~W}$ & $3.47 \mathrm{~W}$ \\
\hline row (2) & $2.90 \mathrm{~W}$ & $3.03 \mathrm{~W}$ & $3.19 \mathrm{~W}$ & $3.18 \mathrm{~W}$ & $3.21 \mathrm{~W}$ & $3.28 \mathrm{~W}$ & $3.31 \mathrm{~W}$ \\
\hline row (3) & $2.84 \mathrm{~W}$ & $2.91 \mathrm{~W}$ & $3.12 \mathrm{~W}$ & $3.12 \mathrm{~W}$ & $3.09 \mathrm{~W}$ & $3.17 \mathrm{~W}$ & $3.25 \mathrm{~W}$ \\
\hline row (4) & $2.61 \mathrm{~W}$ & $2.65 \mathrm{~W}$ & $2.85 \mathrm{~W}$ & $2.85 \mathrm{~W}$ & $2.86 \mathrm{~W}$ & $2.92 \mathrm{~W}$ & $2.98 \mathrm{~W}$ \\
\hline row (5) & $2.52 \mathrm{~W}$ & $2.64 \mathrm{~W}$ & $2.79 \mathrm{~W}$ & $2.81 \mathrm{~W}$ & $2.85 \mathrm{~W}$ & $2.88 \mathrm{~W}$ & $2.96 \mathrm{~W}$ \\
\hline row $(6)$ & $2.42 \mathrm{~W}$ & $2.51 \mathrm{~W}$ & $2.65 \mathrm{~W}$ & $2.69 \mathrm{~W}$ & $2.74 \mathrm{~W}$ & $2.78 \mathrm{~W}$ & $2.83 \mathrm{~W}$ \\
\hline row $(7)$ & $2.14 \mathrm{~W}$ & $2.25 \mathrm{~W}$ & $2.42 \mathrm{~W}$ & $2.43 \mathrm{~W}$ & $2.48 \mathrm{~W}$ & $2.60 \mathrm{~W}$ & $2.63 \mathrm{~W}$ \\
\hline row $(8)$ & $1.96 \mathrm{~W}$ & $2.08 \mathrm{~W}$ & $2.28 \mathrm{~W}$ & $2.29 \mathrm{~W}$ & $2.35 \mathrm{~W}$ & $2.35 \mathrm{~W}$ & $2.41 \mathrm{~W}$ \\
\hline row (9) & $1.86 \mathrm{~W}$ & $1.94 \mathrm{~W}$ & $2.03 \mathrm{~W}$ & $2.10 \mathrm{~W}$ & $2.18 \mathrm{~W}$ & $2.18 \mathrm{~W}$ & $2.29 \mathrm{~W}$ \\
\hline
\end{tabular}

TABLE VIII

Normalised POWER IN the MPP $\left(\hat{P}_{m p p}\right)$ AT DifFerent SOLAR ALtitude ANGLES $(\alpha), \alpha=38^{\circ}$ TO $44^{\circ}$

\begin{tabular}{|c|c|c|c|c|c|c|c|}
\cline { 2 - 8 } \multicolumn{1}{c|}{} & \multicolumn{7}{c|}{ solar altitude angle $(\alpha)$} \\
\cline { 2 - 8 } \multicolumn{1}{c|}{} & $38^{\circ}$ & $39^{\circ}$ & $40^{\circ}$ & $41^{\circ}$ & $42^{\circ}$ & $43{ }^{\circ}$ & $44{ }^{\circ}$ \\
\hline row (1) & $100.00 \%$ & $100.00 \%$ & $100.00 \%$ & $100.00 \%$ & $100.00 \%$ & $100.00 \%$ & $100.00 \%$ \\
\hline row (2) & $92.88 \%$ & $94.33 \%$ & $93.10 \%$ & $93.71 \%$ & $95.39 \%$ & $95.73 \%$ & $95.32 \%$ \\
\hline row (3) & $90.93 \%$ & $90.54 \%$ & $91.33 \%$ & $91.89 \%$ & $91.91 \%$ & $92.49 \%$ & $93.65 \%$ \\
\hline row (4) & $83.63 \%$ & $82.62 \%$ & $83.36 \%$ & $84.09 \%$ & $85.15 \%$ & $85.37 \%$ & $85.79 \%$ \\
\hline row (5) & $80.78 \%$ & $82.27 \%$ & $81.59 \%$ & $82.87 \%$ & $84.81 \%$ & $84.03 \%$ & $85.28 \%$ \\
\hline row (6) & $77.58 \%$ & $78.19 \%$ & $77.40 \%$ & $79.37 \%$ & $81.40 \%$ & $81.30 \%$ & $81.45 \%$ \\
\hline row (7) & $68.51 \%$ & $70.04 \%$ & $70.80 \%$ & $71.68 \%$ & $73.72 \%$ & $76.11 \%$ & $75.59 \%$ \\
\hline row (8) & $62.81 \%$ & $64.72 \%$ & $66.73 \%$ & $67.48 \%$ & $69.97 \%$ & $68.53 \%$ & $69.41 \%$ \\
\hline row (9) & $59.61 \%$ & $60.46 \%$ & $59.29 \%$ & $61.89 \%$ & $64.85 \%$ & $63.60 \%$ & $66.06 \%$ \\
\hline
\end{tabular}

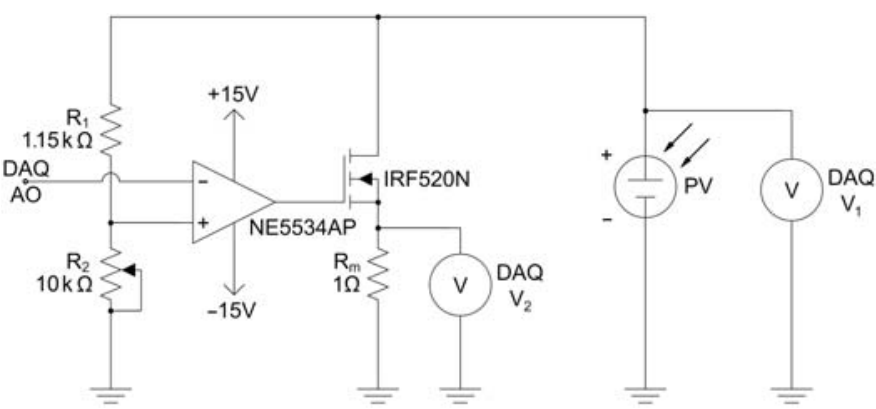

Fig. 8. Schematic diagram of the measurement circuit

Similar to the calculation of the effective area, the values for measured power were normalised. Here, $100 \%$ represents the highest value for the power in MPP $\left(P_{m p p}\right)$, which was measured in a particular row $(i)$, calculated as follows

$$
\hat{P}_{m p p}=\frac{P_{m p p, i}}{P_{\operatorname{mpp}, \max }} \quad \text { whereas } \quad i=1,2, \ldots, 8,9
$$

Table VIII presents the normalised power in the MPP $\left(\hat{P}_{m p p}\right)$. This table is used for the comparison of the experimental results with the calculated normalised effective area $\left(\hat{A}_{e f f}\right)$. An error $\varepsilon$ between $\hat{A}_{\text {eff }}$ and $\hat{P}_{m p p}$ is calculated for every row, as calculated in Equation (5). Fig 9 shows the obtained mean value of the error $(\bar{\varepsilon})$ between $\hat{A}_{\text {eff }}$ and $\hat{P}_{\text {mpp }}$ for different rows of PV cells. As seen in Fig. 9, there is a good agreement between the calculated effective area and the obtained power the MPP. The error including the standard deviation is less than $2.5 \%$. In this way, the effective area can be used for considering different longitudinal angles of PV cells on top of curved surfaces and calculating the output power at different longitudinal angles.

$$
\varepsilon_{i}=\hat{A}_{e f f, i}-\hat{P}_{m p p, i} \quad \text { whereas } \quad i=1,2, \ldots, 8,9
$$

By calculating the effective area, there is no need to measure the ambient conditions for PV cells with different longitudinal angles. For example, the conditions can be measured for the PV cell in row (6) with $\beta=0^{\circ}$, and then the differences can be estimated for PV cells in other rows. Similarly, the power in the MPP needs to be obtained only from one PV cell in one row and can then be estimated for other rows. As BEVs and HEVs have varying roof shapes and allow different amounts of PV cells with different longitudinal angles, the effective area is helpful to investigate the mismatch in terms of output power between PV cells. Here, the effective area can be used as an indicator to determine suitable interconnections of PV cells to form a PV panel. 


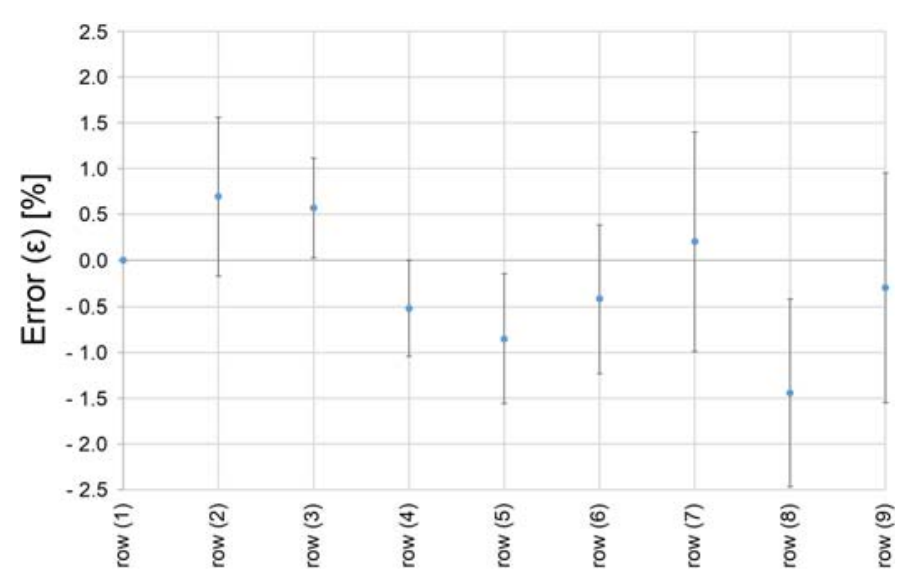

Fig. 9. $\bar{\varepsilon}$ between $\hat{A}_{\text {eff }}$ and $\hat{P}_{m p p}$ for different rows of PV cells

\section{CONCLUSION}

On top of flat surfaces, each PV cell of a PV panel faces the sun under the same angle. Hence, the solar radiation level is equal for every PV cell. In a PV simulation model, the output power of one PV cell is calculated and then multiplied by the factors $N_{s}$ and $N_{s}$ for different series/parallel configurations. However, if PV cells are mounted onto the top of curved surfaces such as the roof of BEVs and HEVs, each PV cell in a row of the installation is oriented under a different longitudinal angle towards the sun.

We demonstrated that the effective area is a simple way to estimate the available power in the MPP of PV cells with different longitudinal angles and can be used for PV simulation models. By normalising values, we were able to compare the values of the calculated effective area and the obtained power in the MPP with each other. We presented experimental results for typical solar altitude angles in the City of Oulu, Finland. In our analysis, we found a strong correlation between the two different parameters. Errors were in the range of less than \pm $2.5 \%$.

\section{ACKNOWLEDGMENT}

We wish to thank Infotech Oulu for financially supporting this research. Prof. Tapio Fabritius was partially funded by the Academy of Finland 6Genesis (6G) project. We appreciate Harald Gall, Klaus Eberhart, Hannes Illko and Suzy McAnsh for their help and comments on this research work.

\section{REFERENCES}

[1] D.P. van Vuuren, N. Nakicenovic, K. Riahi, A. Brew-Hammond, D. Kammen, V. Modi, and K. Smith, "An energy vision: The transformation towards sustainability - interconnected challenges and solutions", Current Opinion in Environmental Sustainability, vol. 4, issue: 1, pp. 18-34, 2012.

[2] S. Mekhilef, R. Saidur, and A. Safari, "A review on solar energy use in industries", Renewable and Sustainable Energy Reviews, vol. 15, issue: 4, pp. 1777-1790, 2011.

[3] C. Schuss, H. Gall, K. Eberhart, H. Illko, and B. Eichberger, "Alignment and Interconnection of Photovoltaics on Electric and Hybrid Electric Vehicles", Proceedings of the IEEE International Instrumentation and Measurement Technology Conference (I2MTC), pp. 524-527, 2014.

[4] K. Araki, L. Ji, G. Kelly, and M. Yamaguchi, "To Do List for Research and Development and International Standardization to Achieve the Goal of Running a Majority of Electric Vehicles on Solar Energy", Coatings, vol. 8, issue: 7, pp. 251, 2018.

[5] T. Masuda, K. Araki, K. Okumura, S. Urabe, Y. Kudo, K. Kimura, T. Nakado, A. Sato, and M. Yamaguchi, "Static concentrator photovoltaics for automotive applications", Solar Energy, vol. 146, pp. 523-531, 2017.

[6] K. Araki, C. Algora, G. Siefer, K. Nishioka, R. Leutz, S. Carter, S. Wang, S. Askins, L. Ji, and G. Kelly, "Standardization of the CPV and car-roof PV technology in 2018 - Where are we going to go?", AIP Conference Proceedings, vol. 2012, no. 1, p. 070001, 2018.

[7] G.C. Mouli, P. Bauer, and M. Zeman, "System design for a solar powered electric vehicle charging station for workplaces", Applied Energy, vol. 168, pp. 434-443, 2016.

[8] G. Leen, and D. Heffernan, "Expanding automotive systems", Computer, vol. 35, issue: 1, pp. 88-93, 2002.

[9] E. Karden, S. Ploumen, B. Fricke, T. Miller, and K. Snyder, "Energy storage devices for future hybrid electric vehicles", Journal of Power Sources, vol. 168, issue: 1, pp. 2-11, 2007.

[10] M.A. Hussin, A.N. Abdalla, R. Ishak, R. Abdullah, and Z.M. Ali, "Study on Improving Electric Vehicle drive range using Solar Energy", International Conference on Electrical, Control and Computer Engineering (InECCE), pp. 373-376, June 2011.

[11] C. Schuss, B. Eichberger, and T. Rahkonen, "A Monitoring System for the Use of Solar Energy in Electric and Hybrid Electric Vehicles", Proceedings of the IEEE International Instrumentation and Measurement Technology Conference (I2MTC), pp. 524-527, 2012.

[12] T. Esram, and P.L. Chapman, "Comparison of Photovoltaic Array Maximum Power Point Tracking Techniques", IEEE Transactions on Energy Conversion, vol. 22, issue: 2, pp. 439-449, 2007.

[13] R. Ramaprabha, B. Mathur, M. Murthy, and S. Madhumitha, "New Configuration of Solar Photo Voltaic Array to address Partial Shaded Conditions", $3^{\text {rd }}$ International Conference on Emerging Trends in Engineering and Technology (ICETET), article number: 5698344, pp. 328-333, 2010.

[14] L. Cai, N. Dai, Z. and Tan, "Research on mathematical model and calculation simulation of wireless sensor solar cells in Internet of Things", EURASIP Journal on Wireless Communications and Networking, vol. 1, p. 116, 2018.

[15] C. Schuss, and T. Rahkonen, "Adaptive Photovoltaic Cell Simulation with Maximum Power Point Tracking Simulation for Accurate Energy Predictions", NORCHIP 2011, article number 6126721, pp. 1-4, 2011.

[16] H.-L. Tsai, "Insolation-oriented model of photovoltaic module using Matlab/Simulink", Solar Energy, vol. 84, issue 7, pp. 1318-1326, 2010.

[17] C. Schuss, B. Eichberger, and T. Rahkonen, "Measurement and Verification of Photovoltaic (PV) Simulation Models", Proceedings of the IEEE International Instrumentation and Measurement Technology Conference (I2MTC), pp. 188-193, 2013. 